\title{
Evidence for a negative feedback in the control of eel growth hormone by thyroid hormones
}

\author{
K Rousseau, N Le Belle, M Sbaihi, J Marchelidon, M Schmitz ${ }^{1}$ \\ and $\mathbf{S}$ Dufour \\ Laboratoire de Physiologie Générale et Comparée, Muséum National d'Histoire Naturelle, Centre National de la Recherche Scientifique, 7 rue Cuvier, \\ 75231 Paris Cedex 05, France \\ ${ }^{1}$ Department of Aquaculture, Swedish University of Agriculture, 90183 Umea, Sweden \\ (Requests for offprints should be addressed to S Dufour; Email: dufour@mnhn.fr)
}

\begin{abstract}
The regulation of growth hormone $(\mathrm{GH})$ by thyroid hormones (THs) has been shown to present species variation. We investigated the regulation of $\mathrm{GH}$ in the eel, a representative of an ancient group of teleosts. In vivo administration of triiodothyronine $\left(T_{3}\right)$ or thyroxine $\left(T_{4}\right)$ significantly reduced pituitary and serum GH levels, as measured by homologous RIA. In order to investigate the ability of THs to regulate GH production directly at the pituitary level, we used a long-term, serum-free primary culture of eel pituitary cells. Both $\mathrm{T}_{3}$ and $\mathrm{T}_{4}$ inhibited $\mathrm{GH}$ release in a concentration-dependent manner, producing up to $50 \%$ inhibition at $10 \mathrm{nM}$, with an $\mathrm{ED}_{50}$ of $<0 \cdot 2 \mathrm{nM}$, within the range of their physiological circulating levels. Other hormones also acting via the nuclear receptor superfamily, such as sex steroids (testosterone, estradiol and progesterone) and corticosteroid (cortisol), had no effect on $\mathrm{GH}$ release in vitro, underlining the specificity of the regulatory effect of THs on GH. Measurement of both GH
\end{abstract}

release and cellular content for calculation of GH production in vitro indicated that $\mathrm{TH}$ not only inhibited $\mathrm{GH}$ release but also GH synthesis. Dot-blot assay of $\mathrm{GH}$ messenger RNA (mRNA) using an homologous eel cDNA probe showed a decrease in GH mRNA levels in cells cultured in the presence of $\mathrm{T}_{3}$, as compared with control cells. This demonstrated that the inhibition of $\mathrm{T}_{3}$ on $\mathrm{GH}$ synthesis was mediated by a decrease in $\mathrm{GH}$ mRNA steady state levels. In conclusion, we demonstrate inhibitory regulation of eel $\mathrm{GH}$ synthesis and release by THs, exerted directly at the pituitary level. These data contrast with the rat, where THs are known to have a stimulatory effect and suggest that the pattern observed here in an early vertebrate and also found in birds, reptiles and some mammals including humans, may represent an ancestral and more generalized vertebrate pattern of $\mathrm{TH}$ regulation of pituitary $\mathrm{GH}$.

Journal of Endocrinology (2002) 175, 605-613

\section{Introduction}

Thyroid hormones (THs) and growth hormone (GH) are thought to play synergistic roles in the control of growth and development in vertebrates (McNabb 1992). Several physiological crosslinks have been demonstrated between thyrotropic and somatotropic axes at peripheral and central levels. In humans (both normal and GH deficient), GH has been shown to act on thyroid function by inducing extrathyroidal conversion of thyroxine $\left(\mathrm{T}_{4}\right)$ to the biologically active hormone, triiodothyronine $\left(\mathrm{T}_{3}\right)$ (Grunfeld et al. 1988). GH has also been reported to increase circulating $\mathrm{T}_{3}$ levels by stimulating peripheral $5^{\prime}$ monodeiodination in birds (Kühn et al. 1987) and teleosts (European eel: de Luze \& Leloup 1984, rainbow trout: MacLatchy et al. 1992). At the pituitary level, thyrotropinreleasing hormone (TRH) was shown to be able to stimulate not only thyrotropin (TSH) but also GH release in various vertebrates including mammals, birds, reptiles, amphibians (Harvey 1990a) and teleosts (Peng \& Peter 1997). Moreover, corticotropin-releasing hormone (CRH) has been shown not only to stimulate corticotropin release but also to act as a GH-releasing factor and TSH-releasing factor in reptiles (Denver \& Licht 1989) and in teleosts (Larsen et al. 1998, Rousseau et al. 1999).

It is well established that $\mathrm{THs}$ are required for normal pituitary GH secretion in man and several other mammalian species (for review: Valcavi et al. 1992, Müller et al. 1999). In the rat and human, hypothyroidism results in impaired basal and stimulated $\mathrm{GH}$ secretion and reduced pituitary GH content, effects which are overcome by restoration of euthyroidism (Williams et al. 1985). However, various reports including data in humans indicated that THs may also exert inhibitory effects on GH. Children with thyrotoxicosis have normal GH responses to provocative stimuli (Katz et al. 1969) but diminished 24-h GH secretion (Finkelstein et al. 1974). In hyperthyroid patients, sleep-related GH release is decreased 
(Sazaki et al. 1985). The action of $T_{3}$ varies across species with reported stimulation in rats (Evans et al. 1982), and inhibition in humans (Cattini et al. 1986) and in bovines (Silverman et al. 1988). This suggests that the welldocumented positive regulation by $\mathrm{T}_{3}$ of rat $\mathrm{GH}$ may not be a common feature among mammalian species.

In birds, $\mathrm{T}_{3}$ exerts a strong inhibitory effect on $\mathrm{GH}$. In vivo, hypothyroidism is a potent stimulator of GH secretion, and exogenous THs markedly suppress GH release (Harvey 1990b, Harvey et al. 1991). A negative effect of $\mathrm{T}_{3}$ on $\mathrm{GH}$ synthesis and release has also been documented in vitro in birds (Denver \& Harvey 1991) and similarly, $\mathrm{T}_{3}$ is reported to exert inhibitory effects on $\mathrm{GH}$ release in vitro in chelonid reptiles (turtles: Denver \& Licht 1988). These data from cattle, humans, birds and reptiles suggest that the more generalized vertebrate pattern of thyroidal regulation of pituitary GH may be inhibitory (Denver \& Harvey 1991). In teleosts, the few data available on the action of THs on GH production are contradictory, reporting no effect (Nishioka et al. 1985, Luo \& McKeown 1991, Moav \& McKeown 1992), inhibitory (Baker \& Ingleton 1975) or stimulatory (Moav \& McKeown 1992, Farchi-Pisanty et al. 1995, Melamed et al. 1995).

Here, we investigated the action of $\mathrm{TH}$ s on $\mathrm{GH}$ release and synthesis in the European eel. The phylogenetic position of the eel, as a member of the Elopomorphs group, an ancient group among teleosts, may provide information on ancestral endocrine regulatory processes in vertebrates (De Pinna 1996). We used a long-term, serum-free system of primary cultures of eel pituitary cells (Rousseau et al. 1998) to investigate the direct pituitary effect of THs on eel GH in vitro. The effects of THs on GH were followed at the protein GH level by homologous RIA of GH cell content and release and at the messenger RNA (mRNA) level by dot-blot using an homologous complementary DNA (cDNA) probe for eel GH. The ability of THs to inhibit $\mathrm{GH}$ was validated by an in vivo study, analyzing their effects on GH serum level and pituitary content.

\section{Materials and Methods}

Fish

Female European eels, Anguilla anguilla L., were netted in ponds in the north and west of France. Animals were transferred to the laboratory and kept in running aerated freshwater for a short time (1 to a few weeks) until experimentation. Animal manipulations were performed according to the recommendations of the French ethical committee and under the supervision of authorized investigators.

\section{Hormones}

$\mathrm{T}_{3}, \mathrm{~T}_{4}$, cortisol, estradiol, progesterone, testosterone and somatostatin (SRIH-14) were obtained from Sigma Chemical Co. (Saint-Quentin Fallavier, France).
In vivo experiments

Hormonal treatments were administered to female silver eels, netted at the time of the downstream migration (November) in ponds in the north of France (Peronne). Eels were transferred to the laboratory and kept in 1001 aquaria ( 8 eels/aquarium) in running aerated freshwater $\left(12 \pm 2{ }^{\circ} \mathrm{C}\right)$. Since at the silver stage eels have initiated a period of physiological fasting, fish were not fed during the experiment. Fish (8 eels/group) received one perivisceral injection per week of $\mathrm{T}_{3}$ or $\mathrm{T}_{4}(2 \mu \mathrm{g} / \mathrm{g}$ body weight) suspended in saline $(0.15 \mathrm{M} \mathrm{NaCl})$ or of saline alone (controls) for 3 months (December-February). No mortality occurred during the experiment. Body weights $\left(282 \pm 11 \mathrm{~g}, 288 \pm 10 \mathrm{~g}, 285 \pm 10 \mathrm{~g}\right.$ for controls, $\mathrm{T}_{3^{-}}$and $\mathrm{T}_{4}$-treated groups respectively at the beginning of the experiment) were reduced by about $10 \%$ at the end of the experiment, with no significant variations between groups $(254 \pm 10 \mathrm{~g}, 263 \pm 9 \mathrm{~g}, 258 \pm 10 \mathrm{~g}$ respectively). The day after the last injection, eels were killed by decapitation. Sera were obtained from blood samples allowed to clot overnight. Pituitaries were quickly removed and kept frozen in $0.15 \mathrm{M} \mathrm{NaCl}$ until extraction.

\section{Primary cultures of eel pituitary cells and in vitro treatments}

In vitro experiments were performed on pituitary cells from batches of yellow (sedentary growth stage) or silver (migratory stage) female eels (body weight 200-300 g) netted the year round in ponds in the west or north of France. A batch of about 100 eels was used for each cell preparation. Each experiment was repeated in three independent studies (performed on different cell preparations from various eel batches). Similar results were obtained with pituitary cell cultures from yellow and silver eels. Results of representative experiments are shown.

Dispersion of pituitary cells was performed using an enzymatic and mechanical procedure as previously described (Rousseau et al. 1998). The number of viable cells, as ascertained by Trypan Blue (Sigma Chemical Co.) exclusion test, represented more than $90 \%$ of the total dispersed cells. Cells were cultured on poly-L-lysine (Sigma Chemical Co.) -precoated plates (Costar, Cambridge, MA, USA) in a serum-free medium (CM; medium 199 with Earle's salt, sodium bicarbonate, 100 $\mathrm{U} / \mathrm{ml}$ penicillin, $100 \mu \mathrm{g} / \mathrm{ml}$ streptomycin, and $250 \mathrm{ng} / \mathrm{ml}$ fungizone; Life Technologies, Cergy-Pontoise, France) at $18{ }^{\circ} \mathrm{C}$ under $3 \% \mathrm{CO}_{2}$ and saturated humidity. Cells were plated on 96-well plates (Costar) at a density of 62500 cells/well for measuring GH by RIA (Montero et al. 1998, Rousseau et al. 1998), or on 12-well plates at a density of 500000 cells/well for measuring mRNAs by dot-blot (Huang et al. 1999a). After 1 day of culture to allow attachment, medium was changed, and treatments were started (day 0).

Stock solutions $\left(10^{-3} \mathrm{M}\right)$ were diluted in $0 \cdot 1 \mathrm{M}$ acetic acid $\left(\mathrm{T}_{3}\right.$ and $\left.\mathrm{T}_{4}\right), 100 \%$ ethanol (cortisol, estradiol, 
progesterone, testosterone) or in pure sterile water (SRIH-14). They were further diluted with CM just before culture medium renewal. The final concentration of acetic acid or ethanol in culture wells never exceeded $0 \cdot 2 \%$; control wells were treated with the same concentration of acetic acid or ethanol in CM. Media were collected and treatments were renewed at each sampling time for up to 12 days. Collected media were kept frozen $\left(-20{ }^{\circ} \mathrm{C}\right)$ until RIA of GH. Cultures were stopped before the addition of hormones (day 0 ) and at the end of the culture for measuring $\mathrm{GH}$ cell content or mRNA levels for $\mathrm{GH}$.

\section{Radioimmunoassays}

Pituitaries were extracted by sonication (Bioblock Scientific, Illkirch, France) in $0.15 \mathrm{M} \mathrm{NaCl}$, and for measurement of $\mathrm{GH}$ cellular contents from in vitro experiments, cells were submitted to osmotic shock (distilled water) and two repeated cycles of freezing and thawing (Rousseau et al. 1998, Huang et al. 1999b).

GH levels from pituitary extracts, sera, cellular contents, and culture media were assayed using an homologous RIA for eel GH (Marchelidon et al. 1996). Results from in vivo studies were expressed as $\mu \mathrm{g} /$ pituitary and $\mathrm{ng} / \mathrm{ml}$. For in vitro studies, total $\mathrm{GH}$ released into the culture medium was determined as cumulative $\mathrm{GH}$ release between each sampling point. GH synthesis in culture was calculated as described (Rousseau et al. 1998, Huang et al. 1999b) and reported as the sum of the cumulative release for 12 days and the variation of cell contents between day 0 and day 12. Results were expressed as nanograms GH per 62500 cells.

\section{GH $c$ DNA probe}

A European eel pituitary cDNA library constructed into $\lambda$ gt10 vector (Quérat et al. 1990) was used to amplify a GH cDNA by PCR. Two primers were designed based on the nucleotide sequences of the Japanese eel GH cDNA (primer 1: 5'-GTTAACC GAGCACAGCA CCT-3'; primer 2: 5'-AGGTCTCCA CTTTGTGCA TGTC-3') (Saito et al. 1988). The conditions for PCR were as follows: $1 \mu \mathrm{l}$ amplified library lysate was mixed with $0.4 \mu \mathrm{M}$ of each primer, $200 \mu \mathrm{M}$ deoxynucleotriphosphates, $10 \mathrm{mM}$ Tris- $\mathrm{HCl}, 1.5 \mathrm{mM} \mathrm{MgCl}$, $50 \mathrm{mM} \mathrm{KCl}$, pH 8.3 and 1 unit Taq DNA polymerase (BoehringerMannheim, Meylan, France) in a final volume of $50 \mu \mathrm{l}$. Cycling parameters were $3 \mathrm{~min}$ denaturation at $94{ }^{\circ} \mathrm{C}$ followed by 30 cycles of $1 \mathrm{~min}$ denaturation at $94^{\circ} \mathrm{C}$, $1 \mathrm{~min}$ annealing at $53^{\circ} \mathrm{C}$ and $1 \mathrm{~min}$ elongation at $72{ }^{\circ} \mathrm{C}$, the final elongation step was extended to $10 \mathrm{~min}$. PCR products were separated by $1.5 \%$ agarose gel electrophoresis, bands excised, purified with JET quick gel extraction kit (GENOMED, Bad Oeynhausen, Germany) and subcloned into pGEMT Easy (Promega-France,
Charbonnières, France). PCR products of three independent PCR amplifications were cloned, sequenced on both strands using a dye terminator cycle sequencing kit (Amersham Life Science-France, Les Ulis, France) and sequence identity performed using the BLAST program (Genbank, NCBI, USA). One major fragment of $481 \mathrm{bp}$ was amplified from the pituitary cDNA ligated into $\lambda$ gt10 vector using primer 1 and primer 2, subcloned and sequenced. Comparison of the nucleotide sequences showed a 98\% nucleotide identity with the Japanese eel GH cDNA (Saito et al. 1988).

\section{Dot-blot assay of GH $m R N A$ s}

Cells were collected and total RNAs were extracted according to the method described by Huang et al. (1999a). Cells were scraped in ice-cold PBS (Life Technologies) using a cell scraper (Costar), centrifuged $(12000 \mathrm{~g})$ for $5 \mathrm{~s}$ at $4{ }^{\circ} \mathrm{C}$, the supernatant was removed, and $45 \mu \mathrm{l}$ TE $(10 \mathrm{mM}$ Tris and $1 \mathrm{mM}$ EDTA, $\mathrm{pH} 7 \cdot 2)$ buffer were added. Cells were then kept at $-80{ }^{\circ} \mathrm{C}$ until RNA extraction. Total RNA was extracted by adding $5 \mu \mathrm{l}$ 5\% Nonidet P-40 (Sigma Chemical Co.) to disrupt cell walls, centrifuged $(12000 \mathbf{g})$ for $15 \mathrm{~min}$ at $4{ }^{\circ} \mathrm{C}$, and the supernatant containing total RNA was collected and denatured at $60{ }^{\circ} \mathrm{C}$ for $15 \mathrm{~min}$ after adding $30 \mu \mathrm{l} 20 \times \mathrm{SSC}$ (standard saline citrate) and $20 \mu \mathrm{l} 37 \%$ formaldehyde. RNA was blotted onto Hybond-N+, Nylon membrane (Amersham Pharmacia Biotech, Les Ulis, France) through a Hybri-blot manifold (Life Technologies). The membrane was air-dried and RNAs were immobilized by baking at $80{ }^{\circ} \mathrm{C}$ for $2 \mathrm{~h}$.

The PCR-derived cDNA fragment of eel GH was $\left[{ }^{32} \mathrm{P}\right] \mathrm{dCTP}-\mathrm{labeled}$ by random priming with the NEBlot-Kit (New England Biolabs, Hitchin, Herts, UK), to a specific activity of $1 \times 10^{9}$ c.p.m. $/ \mu \mathrm{g}$ and used as a probe. The membrane was prehybridized for $5 \mathrm{~h}$ at $42{ }^{\circ} \mathrm{C}$ in hybridization solution (ULTRAhybTM, Ambion, Clinisciences, Montrouge, France) and then hybridized with the ${ }^{32} \mathrm{P}-$ labeled eel GH cDNA overnight at $42{ }^{\circ} \mathrm{C}$. After high stringency washing $(0 \cdot 1 \times$ SSC and $0 \cdot 1 \%$ SDS for $30 \mathrm{~min}$ at $60^{\circ} \mathrm{C}$ ), the membranes were autoradiographed. Scanning densitometry and data processing were performed using a PhosphorImager (Molecular Dynamics, Sunnyvale, CA, USA). The membranes were stripped by boiling in $0 \cdot 1 \%$ SDS and subsequently hybridized under the same conditions with ${ }^{32} \mathrm{P}$-labeled eel $\beta$-actin probe.

\section{Statistical analysis}

For in vitro experiments, replicates of six wells (62 500 cells/well) for RIA studies or of four wells (500 000 cells/well) for mRNA studies, were used for each treatment, and the means \pm S.E.M. are given. For in vivo experiments, groups of eight eels were used for each treatment, and the means \pm S.E.M. are given. Homogeneity 
of variance was assessed by Bartlett's test, and data compared by one-way ANOVA followed by StudentNewman-Keul's multiple comparison test, using InStat (GraphPad Software, Inc., San Diego, CA, USA).

\section{Results}

In vivo effects of $T_{3}$ and $T_{4}$ on pituitary $G H$ content and serum GH level (Fig. 1)

GH pituitary content was high in control eels $(102 \pm 16 \mu \mathrm{g} /$ pituitary), in agreement with previous studies (Marchelidon et al. 1996). Chronic treatment with $\mathrm{T}_{3}$ or $\mathrm{T}_{4}$ significantly $(P<0 \cdot 05)$ reduced eel pituitary GH content by about $50 \%$ of control values (Fig. 1a). Serum $\mathrm{GH}$ level $(3.4 \pm 0.6 \mathrm{ng} / \mathrm{ml})$ was also significantly $(P<0 \cdot 05)$ reduced by $50 \%$ with $\mathrm{T}_{3}$ or $\mathrm{T}_{4}$ treatment (Fig. 1b).

Kinetics of in vitro effects of $T_{3}$ and $T_{4}$ on GH release comparison with SRIH effect (Fig. 2)

We investigated whether the inhibitory effects of $T_{3}$ and $\mathrm{T}_{4}$ on $\mathrm{GH}$ levels could result from a direct pituitary action. Pituitary cells were cultured in serum-free medium to avoid interaction with hormones and growth factors contained in serum (Rousseau et al. 1998). In control wells, sustained GH release was observed throughout the duration of culture (Fig. 2). The total amount of GH released into the medium over 12 days $(18 \pm 1 \mu \mathrm{g} / 62500$ cells $)$ represented $170 \%$ of the initial cell content (day 0: $11 \pm 1 \mu \mathrm{g} / 62500$ cells), reflecting active synthesis of $\mathrm{GH}$ during the culture, as reported previously (Rousseau et al. 1998, 1999).

Addition of $T_{3}$ or $T_{4}(100 \mathrm{nM})$ significantly decreased GH release; the inhibitory effects of $T_{3}$ and $T_{4}$ were significant after $48 \mathrm{~h}$ of incubation $(P<0.05)$ and were maintained up to the end of the culture on day 12 $(P<0 \cdot 001$; Fig. 2$)$. Total GH release over 12 days of culture was decreased by $50 \%$ by $\mathrm{T}_{3}$ and $\mathrm{T}_{4}(P<0 \cdot 001)$.

The addition of SRIH (100 nM) significantly decreased $\mathrm{GH}$ release at each time period of incubation over 12 days $(P<0 \cdot 001)$, in agreement with our previous studies (Rousseau et al. 1998). After 12 days of culture, GH release was reduced by $95 \%$ as compared with controls, an inhibitory effect much stronger than that produced by $\mathrm{T}_{3}$ or $\mathrm{T}_{4}(P<0 \cdot 001$; Fig. 2$)$.

Measurement of GH cellular content at the beginning and at the end of the culture, and of total GH release, allowed us also to estimate the effect of $\mathrm{T}_{3}$ on $\mathrm{GH}$ synthesis in vitro. Control cells showed a sustained synthesis of $\mathrm{GH}$ over 12 days of culture. Culture in the presence of $100 \mathrm{nM} \mathrm{T}_{3}$ induced a significant reduction in $\mathrm{GH}$ synthesis, with a value after 12 days $(4 \pm 0.5 \mu \mathrm{g} /$ 62500 cells) which was significantly lower $(P<0 \cdot 001)$ than in control cells $(10 \pm 1 \mu \mathrm{g} / 62500$ cells).

\section{a) GH pituitary content}

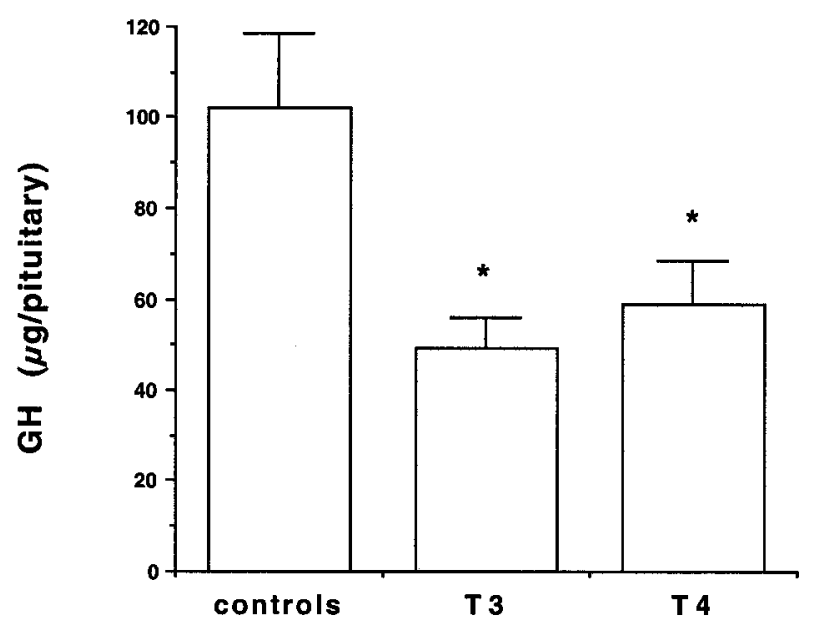

b) $\mathrm{GH}$ serum level

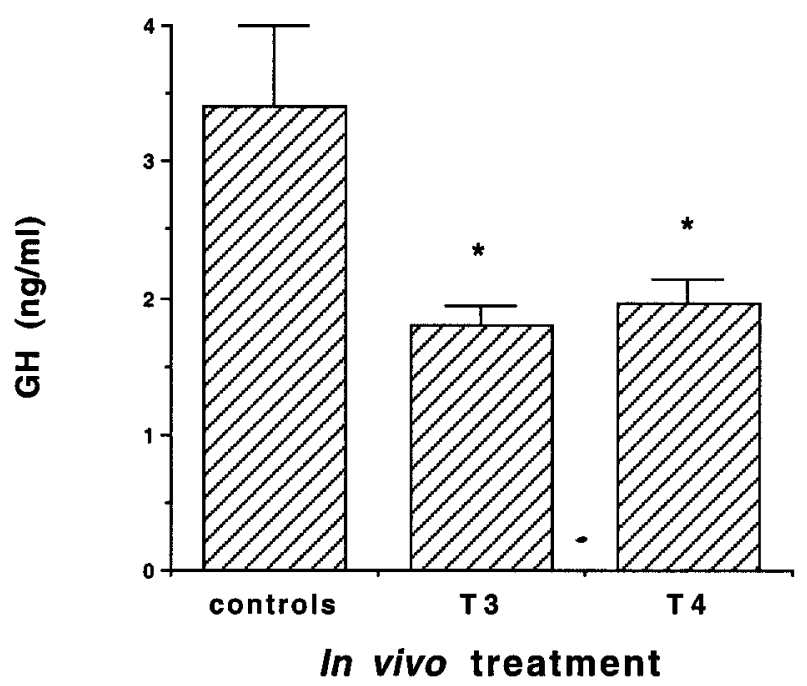

Figure 1 Effect of in vivo treatments with $\mathrm{T}_{3}$ or $\mathrm{T}_{4}$ on $\mathrm{GH}$ pituitary content (a) and serum level (b). Eels received one weekly injection of $2 \mu \mathrm{g} \mathrm{T}_{3}$ or $\mathrm{T}_{4}$ in saline/g body weight for 3 months. Controls were injected with saline alone $(0.15 \mathrm{M} \mathrm{NaCl})$. $\mathrm{GH}$ was measured by homologous RIA. The means \pm S.E.M. are given ( $n=8$ eels/group). ${ }^{*} P<0.05$ vs controls (by variance analysis).

Concentration-dependence of $T_{3}$ and $T_{4}$ effects on $G H$ release in vitro - comparison with SRIH (Fig. 3)

Cultured pituitary cells were incubated with various concentrations of $\mathrm{T}_{3}$ or $\mathrm{T}_{4}(0 \cdot 001$ to $1000 \mathrm{nM})$ for 12 days. The release of $\mathrm{GH}$ in the medium was decreased in a concentration-dependent manner by both $T_{3}$ and $T_{4}$ (Fig. 3). Both $T_{3}$ and $T_{4}$ produced similar maximal inhibitory effects (about $45 \%$ of control values) and maximal inhibition was produced at $T_{3}$ or $T_{4}$ concentrations of 


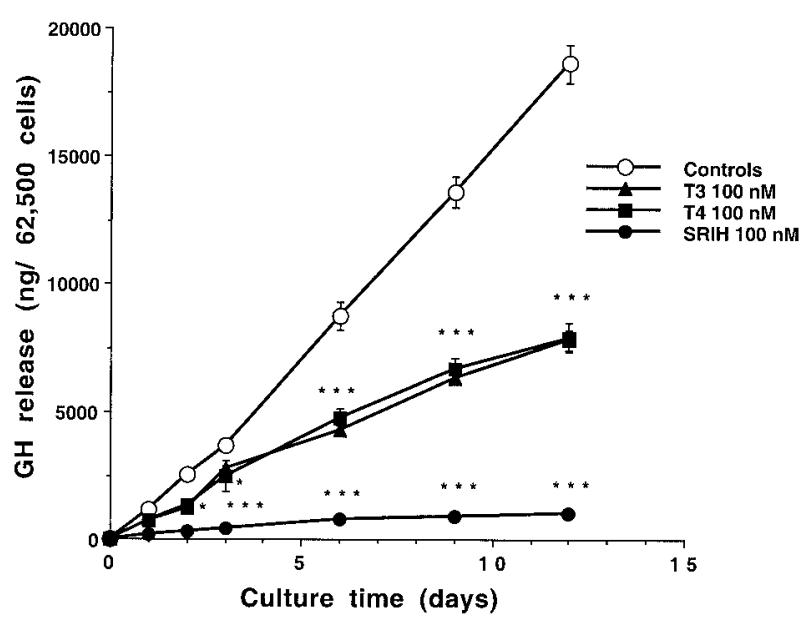

Figure 2 Kinetics of the effects of thyroid hormones $\left(\mathrm{T}_{3}\right.$ or $\left.\mathrm{T}_{4}\right)$ and somatostatin (SRIH) on GH release by primary culture of eel pituitary cells. Cells were cultured in the absence (controls) or presence of $100 \mathrm{nM} \mathrm{T}_{3}, \mathrm{~T}_{4}$ or SRIH. Culture media and hormone treatments were renewed at each sampling time. Total $\mathrm{GH}$ release was calculated by cumulating $\mathrm{GH}$ released between each sampling time up to 12 days. GH was measured by homologous RIA. The means \pm S.E.M. are given $(n=6$ wells/group; 62500 cells/well). ${ }^{*} P<0 \cdot 05$ and ${ }^{* * *} P<0 \cdot 001$ vs controls.

$\geq 10 \mathrm{nM}$. The median efficient dose $\left(\mathrm{ED}_{50}\right)$ was $<0 \cdot 2 \mathrm{nM}$ for both hormones, with no significant differences between $\mathrm{T}_{3}$ and $\mathrm{T}_{4}$.

For comparison, the effects of various concentrations of SRIH $(0.001$ to $1000 \mathrm{nM})$ were tested in the same conditions. SRIH induced a concentration-dependent inhibition of $\mathrm{GH}$ release up to a maximal effect (5\% of control values) significantly greater than the suppression by $\mathrm{T}_{3}$ or $\mathrm{T}_{4}(P<0 \cdot 001)$ (Fig. 3).

Specificity of $T_{3}$ and $T_{4}$ effects on GH release - comparison with effects of other hormones in vitro (Fig. 4)

To test the specificity of TH action on GH release, we compared the effects of different concentrations $(0 \cdot 001$ to $1000 \mathrm{nM}$ ) of various steroid hormones which also act via nuclear receptors. In contrast to the concentrationdependent inhibitory effects of $\mathrm{T}_{3}$ and $\mathrm{T}_{4}$, cortiscosteroid (cortisol) and sex steroids (testosterone, estradiol and progesterone) had no significant effect on GH release at any concentration tested, up to 12 days of culture (Fig. 4).

\section{Effect of $T_{3}$ on $\mathrm{GH} m \mathrm{mNA}$ levels in vitro (Fig. 5)}

In order to further investigate the inhibitory action of $\mathrm{T}_{3}$ on GH synthesis, we analyzed whether it implicated an action at the level of transcription.

Cell cultures were stopped for mRNA measurement before (day 0 ) or after various days in the presence or not of $100 \mathrm{nM} \mathrm{T}_{3}$ (Fig. 5a,b). GH mRNA levels increased

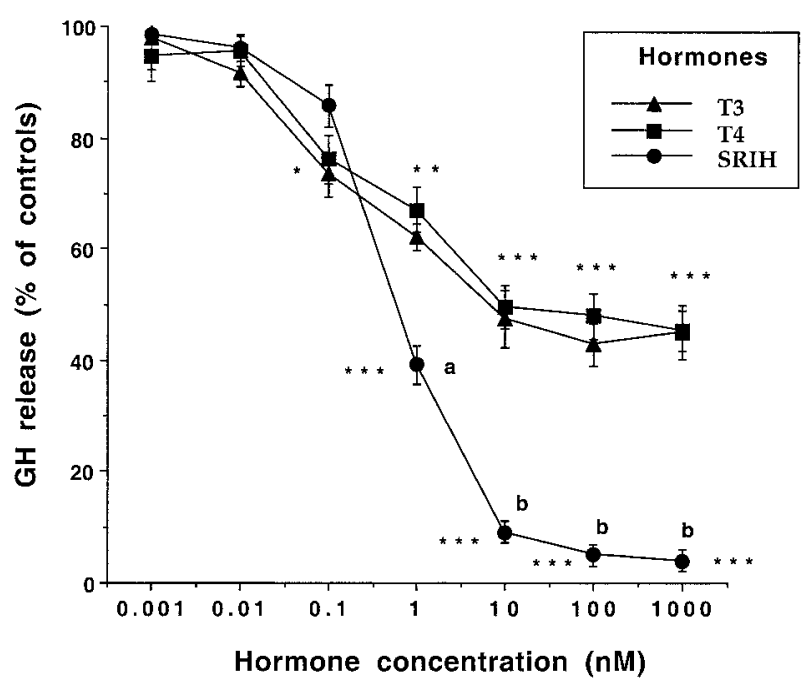

Figure 3 Concentration-dependent inhibitory effects of $T_{3}, T_{4}$ and SRIH on GH release by primary culture of eel pituitary cells. Cells were cultured for 12 days in the absence (controls) or in the presence of various concentrations of $\mathrm{T}_{3}, \mathrm{~T}_{4}$ or SRIH $(0 \cdot 001$ to $1000 \mathrm{nM})$. Culture media and hormone treatment were renewed every third day. Total $\mathrm{GH}$ release was calculated by cumulating $\mathrm{GH}$ released every third day up to 12 days. Results are expressed as percentage of mean control values (13 $500 \pm 690 \mathrm{ng}$ ). The means \pm S.E.M. are given ( 6 wells/group; 62500 cells/well). ${ }^{*} P<0.05,{ }^{* *} P<0.01$ and ${ }^{* * *} P<0.001$ vs controls. ${ }^{a} P<0.01$ and ${ }^{\mathrm{b}} P<0 \cdot 001$ : significant differences between $\mathrm{SRIH}$ - and $\mathrm{T}_{3} / \mathrm{T}_{4}{ }^{-}$ inhibitory effects, at the same hormone concentration.

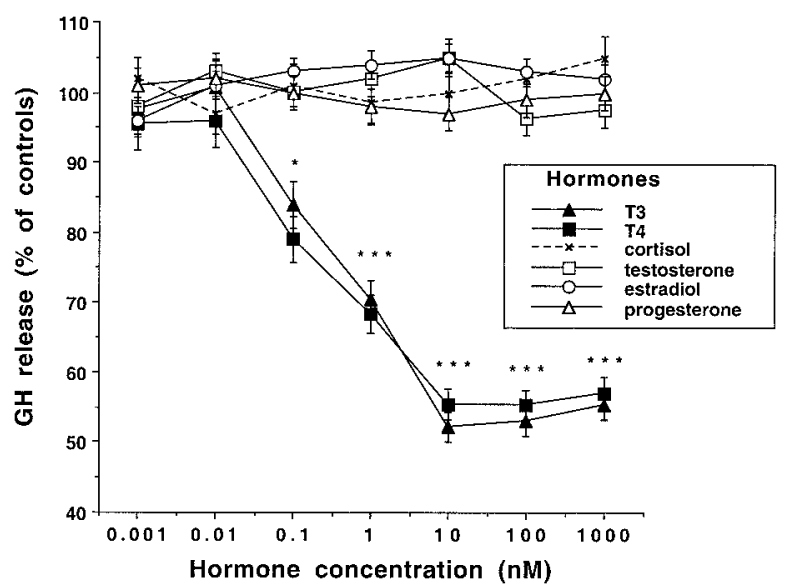

Figure 4 Comparative effects of $\mathrm{T}_{3}, \mathrm{~T}_{4}$ and other hormones that act via the nuclear receptor superfamily (corticosteroid: cortisol and sex steroids: testosterone, estradiol, progesterone) on $\mathrm{GH}$ release by primary culture of eel pituitary cells. Cells were cultured for 12 days in the absence (controls) or in the presence of various concentrations ( 0.001 to $1000 \mathrm{nM})$ of $\mathrm{T}_{3}, \mathrm{~T}_{4}$, or of steroids. Culture media and hormone treatment were renewed every third day. Total GH release was calculated by cumulating $\mathrm{GH}$ released every third day up to 12 days. Results are expressed as a percentage of mean control values $(8750 \pm 450 \mathrm{ng})$. The means \pm S.E.M. are given ( $n=6$ wells/group; 62500 cells/well). ${ }^{*} P<0.05$ and ${ }^{* *} P<0.001$ vs controls. 


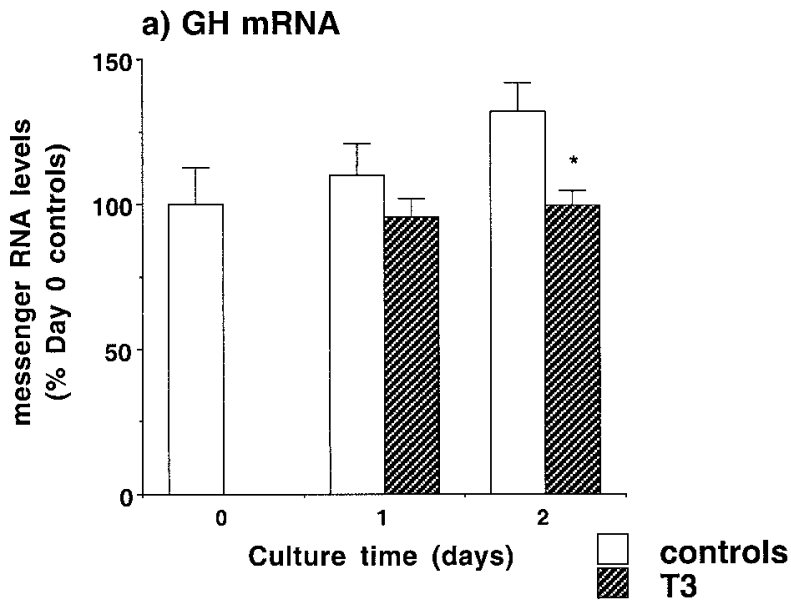

b) GH and actin mRNAs

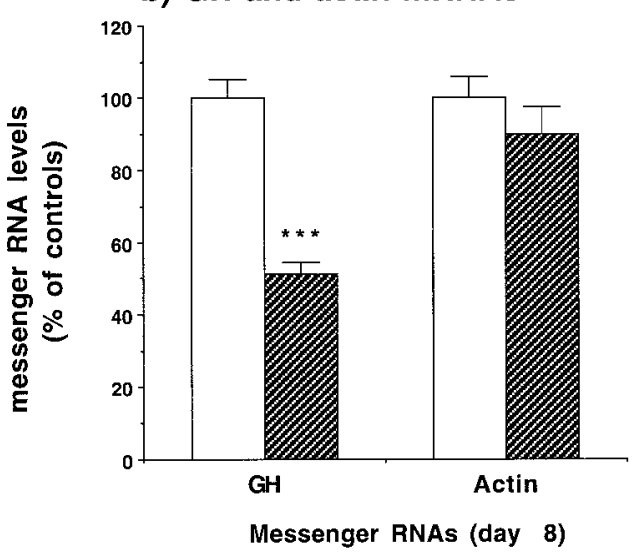

Figure 5 Effect of $\mathrm{T}_{3}$ on $\mathrm{GH}$ mRNA levels in primary culture of eel pituitary cells. Cells were cultured for 1 and 2 days (a) or for 8 days (b) in the absence (controls) or presence of $100 \mathrm{nM} \mathrm{T}_{3}$. GH mRNA levels and $\beta$-actin mRNA levels were measured by dot-blot, using homologous cDNA probes for eel $\mathrm{GH}$ and $\beta$-actin. The means \pm S.E.M. are given ( $n=4$ wells/group; 500000 cells/well). ${ }^{*} P<0.05$ and ${ }^{* * *} P<0 \cdot 001$ vs respective controls.

significantly with culture time in control cells (Fig. 5a; $P<0.05$ between day 2 and day 0 controls). The presence of $\mathrm{T}_{3}$ blocked this increase in $\mathrm{GH}$ transcription, and this inhibitory effect was significant after 2 days of culture (Fig. $5 \mathrm{a}, \times 0.75$ control values, $P<0 \cdot 05)$. The inhibitory effect of $\mathrm{T}_{3}$ was specifically exerted on GH mRNA levels (Fig. $5 \mathrm{~b} ; \times 0.5$ control values after 8 days of treatment, $P<0 \cdot 001)$, no change in $\beta$-actin mRNA levels being observed (Fig. 5b).

\section{Discussion}

Chronic administration of thyroid hormones $\left(\mathrm{T}_{3}\right.$ or $\left.\mathrm{T}_{4}\right)$ significantly decreased both GH pituitary content and serum concentration, indicating that $\mathrm{TH}$ s inhibit $\mathrm{GH}$ synthesis and release in vivo in the eel. The in vivo experiment was performed at the silver stage, when eels are physiologically fasting, in order to avoid possible indirect effects of THs on food intake and metabolism. Accordingly, no significant differences in body weight were observed between control and $\mathrm{T}_{3^{-}}$or $\mathrm{T}_{4}$-treated fish at the end of the experiment. However, in vivo inhibitory effects of THs on GH could still reflect indirect actions such as changes in $\mathrm{GH}$ response to fasting (Marchelidon et al. 1996) or other indirect pathways.

In order to investigate whether THs were acting directly at the pituitary level to inhibit GH production, we used a serum-free primary culture of pituitary cells. $\mathrm{T}_{3}$ and $\mathrm{T}_{4}$ decreased $\mathrm{GH}$ release in vitro in a concentrationdependent manner with a maximal suppression of about $50 \%$, similar to that observed in vivo. These data contrast with our earlier studies in which we demonstrated that THs had no effect on luteinizing hormone ( $\mathrm{LH}$ ) production by gonadotropes under the same culture conditions (Huang et al. 1998), assessing the specificity of $\mathrm{TH}$ inhibitory effect on somatotrophs. We further investigated the specificity of $\mathrm{TH}$ action by comparing the activities of various hormones also acting via the same molecular family of nuclear receptors, such as sex steroids and corticosteroids (Glass 1994). None of the steroids tested (androgen: testosterone; estrogen: estradiol; progestagen: progesterone and glucocorticosteroid: cortisol) had any significant effect on GH release, in contrast to our earlier studies in which we demonstrated stimulatory effects of testosterone and cortisol on LH (Huang et al. 1999a).

In the eel, $\mathrm{T}_{3}$ and $\mathrm{T}_{4}$ had similar maximal inhibitory effects on $\mathrm{GH}$ release in vitro at concentrations within the physiological range (4 to $8 \mathrm{nM}$ ) (de Luze \& Leloup 1984). These inhibitory effects of TH could be observed throughout the 12-day period of culture, indicating no desensitization. This suggests that THs may exert a physiological and chronic role in the negative regulation of GH levels in the eel. Support for this hypothesis comes from studies reporting significant inhibition of $\mathrm{GH}$ release by pituitaries cultured for 6 days in the presence of a high dose $(1 \mu \mathrm{g} / \mathrm{ml})$ of $T_{4}$ (Baker \& Ingleton 1975). Our data on dispersed cultured cells indicate that the effect of $\mathrm{TH}$ acts directly on pituitary cells and is not mediated by the hypothalamic axonal endings which directly innervate the adenohypophysis in teleosts. These data are thus the first demonstration of an inhibitory effect of $\mathrm{TH}$ on $\mathrm{GH}$ release in vivo and in vitro in a teleost species. Indeed, previous studies in teleosts failed to show any significant alterations of $\mathrm{GH}$ in response to $\mathrm{T}_{3}$ in vivo (rainbow trout: Moav \& McKeown 1992) and in vitro (tilapia: Nishioka et al. 1985, carp: Luo \& McKeown 1991).

These inhibitory effects of TH on GH in the eel are similar to those previously demonstrated in tetrapod vertebrates. In the chicken, exogenous TH markedly suppressed circulating GH levels, while thyroidectomy or goitrogen treatment resulted in a rise in the basal GH level 
(Harvey et al. 1988). $\mathrm{T}_{3}$ also suppressed basal as well as TRH- or growth hormone-releasing hormone (GHRH)induced GH secretion in vivo in euthyroid and hypothyroid chicken (Scanes \& Harvey 1989), an inhibitory effect also evidenced in vitro (Harvey 1990b). In chelonian reptiles, THs were shown to act directly at the level of the pituitary to inhibit basal and TRH-induced GH secretion in vitro (Denver \& Licht 1988). In humans, although THs are required for normal GH secretion (Valcavi et al. 1992, Müller et al. 1999), they have also been shown to reduce it in vivo in hyperthyroid patients (Sazaki et al. 1985) and in adolescents with thyrotoxicosis (Finkelstein et al. 1974). $\mathrm{T}_{3}$ has also been shown to inhibit $\mathrm{GH}$ release in vitro from fetal pituitary cells (Mulchahey et al. 1988) and from pituitary tumor cells of acromegalic patients (Adams et al. 1981). In contrast, in the rat, positive effects of THs on $\mathrm{GH}$ secretion have been emphasized in vivo (Peake et al. 1973, Coiro et al. 1979, Martin et al. 1985) and in vitro (Hinkle \& Goh 1982).

In the eel, comparison of $\mathrm{T}_{3}$ and $\mathrm{T}_{4}$ dose-dependent effects in vitro indicated that both hormones had a similar maximal effect and $\mathrm{ED}_{50}$, suggesting that they were acting through similar mechanisms. In teleost pituitaries, nuclear $\mathrm{TH}$ binding sites have been described which bind $\mathrm{T}_{3}$ with approximately 20-50 times greater affinity than $\mathrm{T}_{4}$, properties closely resembling those of mammalian $\mathrm{TH}$ nuclear receptors (Bres \& Eales 1990). These data suggest that $T_{4}$, because of its weaker affinity for the receptor, may act after deiodination into $T_{3}$ (McNabb 1992). Local deiodination of $\mathrm{T}_{4}$ into $\mathrm{T}_{3}$ is regulated by type II and type I 5'-deiodinases in rat anterior pituitary cells (Köhrle et al. 1995). Although deiodinase activities have been characterized in various tissues in teleosts, including liver, kidney, gill and brain (Eales et al. 1993), the existence of such enzymes in the pituitary has not yet been determined. The high capacity of $\mathrm{T}_{4}$ to inhibit $\mathrm{GH}$ release in the eel in vitro likely reflects the presence of an active pituitary deiodinase. A similar conclusion was previously raised in view of the similar efficiency of both $T_{3}$ and $T_{4}$ to inhibit TSH mRNA levels in eel pituitary cells, in the same culture conditions (Pradet-Balade et al. 1997). In the turtle, $\mathrm{T}_{3}$ and $\mathrm{T}_{4}$ also had similar inhibitory effects on $\mathrm{GH}$ secretion in vitro (Denver \& Licht 1988). In contrast, in the domestic fowl, $\mathrm{T}_{3}$, but not $\mathrm{T}_{4}$, has been shown to inhibit GH secretion in vitro (Harvey et al. 1991). In the rat, in hyperthyroid states, GH mRNA levels are stimulated by $\mathrm{T}_{3}$ generated by type I $5^{\prime}$-deiodinase, whereas in hypothyroidism, when type II $5^{\prime}$-deiodinase activity is markedly increased, GH mRNA is more responsive to $\mathrm{T}_{4}$ (Volpato \& Nunes 2001). This suggests inter-species variability in pituitary deiodinase activity, which may modulate the direct action of $\mathrm{T}_{4}$.

In the eel, evaluation of GH synthesis in vitro indicated that $\mathrm{TH}$ not only reduced GH release but also significantly inhibited GH synthesis. This corroborates the inhibitory effect of $\mathrm{TH}$ on both pituitary $\mathrm{GH}$ content and release
Hypothalamus

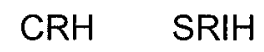

\section{Thyroid \\ Periphery}

Pituitary

Figure 6 Multiple cross-links between the somatotrope and the thyrotrope axes in the eel. Brain neurohormones, somatostatin $(\mathrm{SRIH})$ and corticotropin-releasing hormone $(\mathrm{CRH})$ control both pituitary growth hormone $(\mathrm{GH})$ and thyrotrope hormone (TSH). TSH stimulates the synthesis of $\mathrm{T}_{4}$ by the thyroid, while $\mathrm{GH}$ activates the peripheral deiodination of $\mathrm{T}_{4}$ into biologically active $T_{3}$. Both $T_{3}$ and $T_{4}$ exert negative feedbacks on pituitary $G H$ and TSH.

in vivo. Similarly, in the domestic fowl, $\mathrm{T}_{3}$ not only inhibited GH release, but also blocked the accumulation of newly synthesized GH through a direct action on the pituitary (Denver \& Harvey 1991). In the present study, we investigated whether the inhibitory effect of $\mathrm{T}_{3}$ on $\mathrm{GH}$ synthesis could be mediated by an inhibition of $\mathrm{GH}$ mRNA levels. After cloning an homologous eel GH cDNA probe, we demonstrated that $\mathrm{T}_{3}$ significantly decreased GH mRNA levels in eel cultured pituitary cells. These data indicate that the $\mathrm{T}_{3}$ inhibitory effect may, at least partly, be mediated by a decrease in GH mRNA steady state levels. In contrast to the present study in the eel, data in other teleost species indicated a stimulatory effect of $\mathrm{T}_{3}$ on $\mathrm{GH}$ mRNA levels. In the carp, $\mathrm{T}_{3}$ increased $\mathrm{GH}$ mRNA levels in pituitary fragments in vitro (Farchi-Pisanty et al. 1995). In the rainbow trout, oneweek $\mathrm{T}_{3}$ treatment in vivo increased steady state levels of GH mRNA but produced no alterations in pituitary or plasma GH levels (Moav \& McKeown 1992). Speciesrelated variations in the effects of $\mathrm{T}_{3}$ on GH mRNA levels were also observed among mammals. In the rat, $\mathrm{T}_{3}$ was shown to stimulate GH mRNA levels in cultured pituitary tumor cell lines (Samuels \& Shapiro 1976). In contrast, $T_{3}$ reduced GH mRNA levels in bovine pituitary cells in vitro (Silverman et al. 1988), a situation similar to that found for human GH (Valcavi et al. 1992). In the rat, the positive effect of $\mathrm{T}_{3}$ on GH mRNA levels has been attributed to a direct stimulatory effect on $\mathrm{GH}$ gene transcription, 
mediated by the presence of positive thyroid responsive elements (TRE) (Theill \& Karin 1993). In contrast, $T_{3}$ blocks human GH gene transcription even after transfection into rat pituitary cells (Cattini et al. 1986, Morin et al. 1990), indicating a regulation opposite to that of the rat $\mathrm{GH}$ gene. In an analysis of rat $\mathrm{GH}$ promoter constructs, Brent et al. (1991) were able to show that varying the position of TRE induced positive or negative regulation by $\mathrm{T}_{3}$.

In conclusion, our study of a primitive teleost demonstrates negative regulation of $\mathrm{GH}$ expression and release exerted by THs acting directly on pituitary cells in vitro. This inhibition, confirmed by in vivo studies, may represent an ancestral negative feedback of $\mathrm{TH}$ s on $\mathrm{GH}$ production, reflecting the crosslink between the thyrotrope and somatotrope axes (Fig. 6). It is clear that variation in the effects of THs on $\mathrm{GH}$ regulation are observed amongst vertebrate species. The negative regulation demonstrated here in an early vertebrate is also observed in birds, reptiles and some mammals including humans. This may represent an ancestral and more generalized vertebrate pattern of $\mathrm{TH}$ regulation of pituitary $\mathrm{GH}$.

\section{Acknowledgements}

We are grateful to B Quérat (CNRS, Paris) for the eel pituitary cDNA library and K Kight (Center of Marine Biotechnology, University of Maryland, Baltimore, USA) for the gift of eel $\beta$-actin probe. We thank Prof. A S I Loudon (University of Manchester, UK) for critical reading of the manuscript and for correcting the English. The work was supported by research grants from Conseil Supérieur de la Pêche (n ${ }^{\circ}$ 00496) and Centre National de la Recherche Scientifique (CNRS/NSF $\mathrm{n}^{\circ}$ 3900) (to $\mathrm{SD})$, a research grant from the Swedish Council for Forestry and Agricultural Research (41.039/97) and a visiting fellowship from MNHN (to M Schmitz), and $\mathrm{PhD}$ fellowships from the Ministry of Research and Education and FRM (Fondation pour la Recherche Médicale) (France) (to K R), and from the Ministry of Education (Syria) (to M Sbaihi).

\section{References}

Adams EF, Brajkovich IE \& Mashiter K 1981 Growth hormone and prolactin secretion by dispersed cell cultures of human pituitary adenomas: long term effects of hydrocortisone, estradiol, insulin, 3,5,3'-triiodothyronine and thyroxine. Journal of Clinical Endocrinology and Metabolism 53 381-386.

Baker BI \& Ingleton PM 1975 Secretion of prolactin and growth hormone by teleost pituitaries in vitro. II. Effect of salt concentration during long-term organ culture. Journal of Comparative Physiology 100 269-282.

Brent GA, Williams GR, Harney JW, Forman BM, Samuels HH, Moore DD \& Larsen PR 1991 Effects of varying the position of thyroid hormone response elements within the rat growth hormone promoter: implications for positive and negative regulation by 3,5,3'-triiodothyronine. Molecular Endocrinology 5 542-548.

Bres O \& Eales JG 1990 Saturable triiodothyronine-binding sites in the pituitary nuclei of salmonid teleost fish. General and Comparative Endocrinology 77 23-28.

Cattini PA, Anderson TR, Baxter JD, Mellon P \& Eberhardt N 1986 The human growth hormone gene is negatively regulated by triiodothyronine when transfected into rat pituitary tumor cells. Journal of Biological Chemistry 261 13367-13372.

Coiro V, Braverman LE, Christianson D, Fang S-L \& Goodman HM 1979 Effect of hypothyroidism and thyroxine replacement on growth hormone in the rat. Endocrinology 105 641-646.

Denver RJ \& Licht P 1988 Thyroid hormones act at the level of the pituitary to regulate thyrotropin and growth hormone secretion in hatchling slider turtles (Pseudemys scripta elegans). Journal of Experimental Zoology 247 146-154.

Denver RJ \& Licht P 1989 Neuropeptides influencing in vitro pituitary hormone secretion in hatchling turtles. Journal of Experimental Zoology 251 306-315.

Denver RJ \& Harvey S 1991 Thyroidal inhibition of chicken pituitary growth hormone: alterations in secretion and accumulation of newly synthesized hormone. Journal of Endocrinology 131 39-48.

De Pinna MCC 1996 Teleostean monophyly. In Interrelationships of Fishes, pp 147-162. Eds MLJ Stiassny, LR Parenti \& GD Johnson. New York: Academic Press.

Eales JG, MacLatchy DL \& Sweeting RM 1993 Thyroid hormone deiodinase systems in salmonids, and their involvement in the regulation of thyroidal status. Fish Physiology and Biochemistry 11 313-321.

Evans R, Birnberg N \& Rosenfeld M 1982 Glucocorticoid and thyroid hormones transcriptionally regulate growth hormone gene expression. PNAS 79 7659-7663.

Farchi-Pisanty O, Kackett PB \& Moav B 1995 Regulation of fish growth hormone transcription. Molecular Marine Biology and Biotechnology 4 215-223.

Finkelstein JW, Boyar RM \& Hellman L 1974 Growth hormone secretion in hyperthyroidism. Journal of Clinical Endocrinology and Metabolism 38 634-637.

Glass GK 1994 Differential recognition of target genes by nuclear receptor monomers, dimers and heterodimers. Endocrine Reviews $\mathbf{1 5}$ 391-406.

Grunfeld C, Sherman BM \& Cavalieri RR 1988 The acute effects of human growth hormone administration on thyroid function in normal men. Journal of Clinical Endocrinology and Metabolism 67 $1111-1114$

Harvey S 1990a Thyrotropin-releasing hormone: a growth hormone-releasing factor. Journal of Endocrinology 125 345-358.

Harvey S $1990 b$ Tri-iodothyronine inhibition of thyrotropin-releasing hormone-induced growth hormone release from the chicken adenohypophysis in vitro. Journal of Endocrinology 126 75-81.

Harvey S, Scanes CG \& Klandorf H 1988 Thyrotropin-releasing hormone induces growth hormone secretion in adult hypothyroid fowl. General and Comparative Endocrinology 69 233-237.

Harvey S, Decuypere E, Darras VM \& Berghman L 1991 Differential effects of $\mathrm{T}_{4}$ and $\mathrm{T}_{3}$ on TRH- and GFR-induced GH secretion in the domestic fowl. Reproduction Nutrition Development 31 451-460.

Hinkle PM \& Goh KB 1982 Regulation of thyrotropin-releasing hormone receptors and responses by L-triiodothyronine in dispersed rat pituitary cell cultures. Endocrinology 110 1725-1731.

Huang YS, Rousseau K, Le Belle N, Vidal B, Burzawa-Gérard E, Marchelidon J \& Dufour S 1998 Insulin-like growth factor-I stimulates gonadotrophin production from eel pituitary cells: a possible metabolic signal for induction of puberty. Journal of Endocrinology 159 43-52.

Huang YS, Rousseau K, Sbaihi M, Le Belle N, Schmitz M \& Dufour S 1999a Cortisol selectively stimulates pituitary gonadotropin $\beta$-subunit in a primitive teleost, Anguilla anguilla. Endocrinology 140 1228-1235. 
Huang YS, Rousseau K, Le Belle N, Vidal B, Burzawa-Gérard E, Marchelidon J \& Dufour S 1999b Opposite effects of insulin-like growth factors (IGFs) on gonadotropin (GtH-II) and growth hormone $(\mathrm{GH})$ production by primary culture of European eel (Anguilla anguilla) pituitary cells. Aquaculture 177 73-83.

Katz HP, Youlton R, Kaplan SL \& Grumbach MM 1969 Growth and growth hormone. III. Growth hormone release in children with primary hypothyroidism and thyrotoxicosis. Journal of Clinical Endocrinology and Metabolism 29 346-351.

Köhrle J, Shomburg L, Drescher S, Fekete E \& Bauer K 1995 Rapid stimulation of type I $5^{\prime}$-deiodinase in rat pituitaries by 3,3',5-triiodothyronine-L-thyronine. Molecular and Cellular Endocrinology 108 17-21.

Kühn ER, Verheyen G, Chiasson RB, Huts C, Huybrechts L, Van den Steen P \& Decuypere E 1987 Growth hormone stimulates the peripheral conversion of thyroxine into triiodothyronine by increasing the liver $5^{\prime}$-monodeiodinase activity in the fasted and normal fed chicken. Hormone and Metabolic Research 19 304-308.

Larsen DA, Swanson P, Dickey JT, Rivier J \& Dickhoff WW 1998 In vitro thyrotropin-releasing activity of corticotropin-releasing hormone-family peptides in coho salmon, Oncorhynchus kisutch. General and Comparative Endocrinology 109 276-285.

Luo D \& McKeown BA 1991 The effect of thyroid hormone and glucocorticoids on carp growth hormone-releasing factor (GRF)-induced growth hormone $(\mathrm{GH})$ release in rainbow trout (Oncorhynchus mykiss). Comparative Biochemistry and Physiology 99A 621-626.

de Luze A \& Leloup J 1984 Fish growth hormone enhances peripheral conversion of thyroxine to triiodothyronine in the eel (Anguilla anguilla L.). General and Comparative Endocrinology 56 308-312.

MacLatchy DL, Kawauchi H \& Eales JG 1992 Stimulation of hepatic thyroxine $5^{\prime}$-deiodinase activity in rainbow trout (Oncorhynchus mykiss) by pacific salmon growth hormone. Comparative Biochemistry and Physiology 101A 689-691.

McNabb FMA 1992 Thyroid Hormones. Prentice Hall Endocrinology Series. Ed. ME Hadley. New Jersey: Englewood Cliffs.

Marchelidon J, Schmitz M, Houdebine LM, Vidal B, Le Belle N \& Dufour S 1996 Development of a radioimmunassay for European eel growth hormone and application to the study of silvering and experimental fasting. General and Comparative Endocrinology 102 360-369.

Martin D, Epelbaum J, Bluet-Pajot M-T, Prelot M, Kordon C \& Durand D 1985 Thyroidectomy abolishes pulsatile growth hormone secretion without affecting hypothalamic somatostatin. Neuroendocrinology 41 476-481.

Melamed P, Eliahu N, Levavi-Sivan B, Ofir M, Farchi-Pisanty O, Rentier-Delerue F, Smal J, Yaron Z, \& Naor Z 1995 Hypothalamic and thyroidal regulation of growth hormone in tilapia. General and Comparative Endocrinology 97 13-30.

Moav B \& McKeown BA 1992 Thyroid hormone increases transcription of growth hormone mRNA in rainbow trout pituitary. Hormone and Metabolic Research 24 10-14.

Montero M, Yon L, Rousseau K, Arimura A, Fournier A, Dufour S \& Vaudry H 1998 Distribution, characterization and growth hormone releasing activity of pituitary adenylate cyclase-activating polypeptide in the European eel, Anguilla anguilla. Endocrinology 139 $4300-4310$

Morin A, Louette J, Voz MLJ, Tixier-Vidal A, Belayew A \& Martial JA 1990 Triiodothyronine inhibits transcription from the human growth hormone promoter. Molecular and Cellular Endocrinology 71 261-267.

Mulchahey JJ, Di Blasio AM \& Jaffe RB 1988 Effects of growth hormone $(\mathrm{GH})$-releasing hormone and somatostatin on $\mathrm{GH}$ secretion from individual human and monkey fetal anterior pituitary cells: modulation by thyroid hormones and glucocorticoids. Journal of Clinical Endocrinology and Metabolism 66 395-401.
Müller EE, Locatelli V \& Cocchi D 1999 Neuroendocrine control of growth hormone secretion. Physiological Reviews 79 511-607.

Nishioka RS, Grau EG \& Bern HA 1985 In vitro release of growth hormone from the pituitary gland of tilapia, Oreochromis mossambicus. General and Comparative Endocrinology 60 90-94.

Peake GT, Birge CA \& Daughaday WH 1973 Alterations of radioimmunoassayable growth hormone and prolactin during hypothyroidism. Endocrinology 92 487-493.

Peng C \& Peter RE 1997 Neuroendocrine regulation of growth hormone secretion and growth in fish. Zoological Studies 36 79-89.

Pradet-Balade B, Schmitz M, Salmon C, Dufour S \& Quérat B 1997 Down-regulation of TSH subunit mRNA levels by thyroid hormones in the European eel. General and Comparative Endocrinology 108 191-198.

Quérat B, Jutisz M, Fontaine YA \& Counis R 1990 Cloning and sequence analysis of the cDNA for the pituitary glycoprotein hormone alpha subunit of the European eel. Molecular and Cellular Endocrinology $71253-259$.

Rousseau K, Huang YS, Le Belle N, Vidal B, Marchelidon J, Epelbaum J \& Dufour S 1998 Long-term inhibitory effects of somatostatin and insulin-like growth factor-I on growth hormone release by serum-free primary culture of pituitary cells from European eel (Anguilla anguilla). Neuroendocrinology 67 301-309.

Rousseau K, Le Belle N, Marchelidon J \& Dufour S 1999 Evidence that corticotropin-releasing hormone acts as a growth hormone-releasing factor in a primitive teleost, the European eel (Anguilla anguilla). Journal of Neuroendocrinology 11 385-392.

Saito A, Sekine S, Komatsu Y, Sato Mi, Hirano T \& Itoh S 1988 Molecular cloning of eel growth hormone cDNA and its expression in Escherichia coli. Gene 73 545-551.

Samuels HH \& Shapiro LE 1976 Thyroid hormone stimulates de novo growth hormone synthesis in cultured GH1 cells: evidence for the accumulation of a rate limiting RNA species in the induction process. PNAS 73 3369-3373.

Sazaki N, Tsuyusaki T, Nakamura H, Sanayama K, Niimi H \& Nakajima H 1985 Sleep related growth hormone release in thyrotoxic patients before and during propylthiouracil therapy. Endocrinologia Japonica 32 39-44.

Scanes CG \& Harvey S 1989 Triiodothyronine inhibition of thyrotropin-releasing hormone- and growth hormone-releasing factor-induced growth hormone secretion in anesthetized chickens. General and Comparative Endocrinology 73 477-484.

Silverman BL, Kaplan SL, Grumbach MM \& Miller WL 1988 Hormonal regulation of growth hormone secretion and messenger ribonucleic acid accumulation in cultured bovine pituitary cells. Endocrinology 122 1236-1241.

Theill LE \& Karin M 1993 Transcriptional control of GH expression and the anterior pituitary development. Endocrine Reviews $\mathbf{1 4}$ 670-689.

Valcavi R, Zini M \& Portioli I 1992 Thyroid hormones and growth hormone secretion. Journal of Endocrinological Investigation $\mathbf{1 5}$ 313-330.

Volpato CB \& Nunes MT 2001 Functional evidence for the presence of type II $5^{\prime}$-deiodinase in somatotropes and its adaptive role in hypothyroidism. Neuroendocrinology 74 220-226.

Williams T, Maxon H, Thorner MO \& Frohman LA 1985 Blunted growth hormone $(\mathrm{GH})$ response to $\mathrm{GH}$-releasing hormone in hypothyroidism resolves in the euthyroid state. Journal of Clinical Endocrinology and Metabolism 61 454-456.

Received 27 August 2002

Accepted 6 September 2002 